Planas, A; Soler, P; Fullana, J; Pallisera, M; Vilà, M. (2011) Student participation in university governance: the opinions of professors and students, Studies in Higher Education, 38 (4), 571-583.

\title{
Student participation in university governance. The opinions of professors and students
}

\author{
Anna Planas, Pere Soler, Judit Fullana, Maria Pallisera and Montserrat Vilà \\ University of Girona, Catalonia, Spain
}

\section{Journal: Student in Higher Education}

\begin{abstract}
This paper focuses on analysing student participation in university governance, with the specific aims of identifying the main obstacles to student participation and offering proposals of how to better facilitate student involvement in the functioning of the university. From research carried out on student questionnaires, teaching staff interviews and student discussion groups, we obtained information regarding the major obstacles to student participation. The methodology employed in this research allows us to compare and contrast the opinions and perceptions of students and teaching staff. Significant differences are identified that highlight the main ways for facilitating change in student participation in the university. The required changes must not only relate to improving the means by which students are informed about ways of participating, they must also influence how universities structure participatory processes, the role of the teaching staff and, specifically, the role of coordinators of those managing bodies closest to the students.
\end{abstract}

Keywords: word; student participation, university governance, students voice, professor, management

\section{Introduction}

In recent years, various studies have been conducted that highlight the importance and relevance of participation, both of young people and citizens in general, in the maintenance and development of the democratic system (Andolina et al. 2003; Becerra 2006; Cainzos 2006; Fundación Kaleidos.red 2003; Rovira 2005; Soler 2005; Vaquero 2004). All of these studies demonstrate the need to consider participation as a dimension of people's quality of life, it being closely related to the processes of social inclusion and identity. Participation is, then, an educational and social process, and must necessarily be taken into account throughout all stages of the education system.

Although participation in university governance may be considered a challenge that concerns all actors within the university community (students, academic staff and managers), in this article we focus solely on student participation. It is worth adding, however, that the participation of academic staff and other 
administrative and service staff is also fundamental in ensuring the participation of the students themselves within an effective model of governance.

In the field of university governance, different authors point out the importance of students' involvement in the governance and functioning of universities. These authors consider this to be the most direct and manifest form of recognising the effective and educational significance of these participative processes (Benedicto and Orán 1999; Lizzio and Wilson 2009; Menon 2003; Zuo and Ratsoy 1999); the fact that most of the decisions taken by the governing body of the university affect students directly is also given as further reason for their participation to be taken into account (Lizzio and Wilson 2009; Menon 2003; Zuo and Ratsoy 1999). In addition to this, the Council of Europe Project on Education for Democratic Citizenship (CC-HER Bureau 2000) highlights the important role of universities in transmitting democratic values. For all of the above reasons, we believe student participation to be an important discussion topic in the context of university institutions. Universities could serve as participative spaces where students learn, through example and practice, democratic principles and how these can be applied to different real-life situations.

This article focuses on analysing student participation in the governance and functioning of the university, with the specific aims of demonstrating the principal difficulties perceived and proposals that may favour the increased and improved involvement of students in these processes. In this respect, on the basis of the empirical work conducted and a review of the documentation, the article provides corroboration of theories, new proposals for action in favour of student participation in the university, and a systematic approach to said participation based on proposals deriving from past experiences. In the first section, we provide the results of research conducted into the participation of young people at centres of higher education. We go on to present research conducted at the University of Girona (UdG) ${ }^{1}$ in Spain, where studies are being conducted into student participation in governance bodies and the perceptions of this participation held by the different groups directly involved in university management - students and teaching staff. Finally, using the data obtained and a comparison with other research on the same subject matter, we conclude with proposals for improvement.

\footnotetext{
${ }^{1}$ The UdG has the same system of government as that established for other Spanish public universities in the Universities Act 6/2001, of 21 December, (BOE 24/12/2001) modified by Organic Act 472007, of 12 April, (BOE 13/04/2007).
} 


\section{Background}

\section{Student participation in university governance}

The trend in models of governance at European universities, despite the diversity and heterogeneity they represent, is towards increased institutional autonomy (and therefore increased financial autonomy), higher levels of accountability and increased managerial governance (De Boer and File 2009; OECD 2008), along with increased power for executive authorities within the higher education institutions, a loss of power and influence among existing collegial bodies (with a formal strengthening of the position of executive head) and an increase in the participation of external stakeholders (OECD 2008). Despite these trends, however, the process of adapting to the new European Higher Education Area (EHEA) and the resulting European guidelines and agreements have made student participation in the university one of the focus points. As an example of this, the Glasgow Declaration "Strong universities for a strong Europe" of 15th April 2005, promoted by the European University Association, states in point five of its introduction: "Universities are committed to improving their governance structures and leadership competencies so as to increase their efficiency and innovative capacity and fulfil their multiple functions". In section four, point 19, it adds: "In order to fulfil these commitments, universities highlight the importance of student involvement as full partners in the process and will search for the means of reinforcing this co-operation in the future".

Studies have been carried out to address this concern and demonstrated the difficulties faced by the university system in incorporating students into the anticipated government structures and spaces. We can cite here the experience of the University of Alberta (Zuo and Ratsoy 1999), or studies related to gender differences in participation in the governance of the University of Ontario (Ahmed et al. 1999). In the European context it is worth highlighting the study carried out by the Council of Europe (CC-HER Bureau 2000), which analysed the measures being taken to promote citizenship and democracy at 15 European Universities and focused specifically on student participation in university governance, and the report compiled by A. Persson (2003), which analyses student participation at university on the basis of a survey of 48 ESIB (European Students' Union) member states. This study considers the opinions of members of university governing councils, academics and students, and finds that all three are generally clearly in favour of increasing student participation. We would also highlight here Menon's analysis (2003) of the pros and cons of students participating in the governance of universities and the empirical studies conducted in this respect, Jonson and Deem's (2003) analysis of the priorities and purposes of higher education institutions in the 21 st century, which includes an analysis of new-managerialism models and different perceptions of students, and the recent study on the perception of student representatives at an Australian university (Lizzio and Wilson 2009). 
Diverse international initiatives have been developed with the aim of finding the best structure and participative processes to allow a better channelling of student participation. The university governing bodies in Canada are considering reviewing the function of the senate as a space for student participation in order to adapt it to current times (Jones et al. 2004). On another level, but with a similar purpose, we find the study by Kuruuzum, Asilkan and Bato (2005), in which they propose, in addition to a review of spaces for student representation and participation, that university departments give more responsibility to the students in activities concerning them, involve them in problems related to the budget and physical resources, and have them participate in setting standards.

Studies carried out on the subject state that the university of today is not perceived, at least not generally, as a privileged space for political learning and social transformation, but rather strictly as a space for academic learning (Becerra 2006) where vocational orientation and technical training programmes are the priority for students (CC-HER Bureau 2000). If the role of university is to equip citizens with the skills to work as professionals, there is a need for a constant and permanent debate on which direction this should take, its ethical limits and the social implications of different disciplines. It is worth considering how to facilitate students' acquisition of competences in political training, social commitment, and concern for social and cultural implications through practice and experience at university. Coming into closer contact with university management and participating in management and decision-making processes is a privilege that allows students to discover, learn about and practise this form of training.

\section{The current situation with regard to student participation in Spanish universities}

In Spain, student participation in the university system is also the object of debate. On the one hand, the Spanish Ministry for Science and Innovation (MICINN) presented, on 22nd January 2009, the Draft university student statute, with the aim of regulating students' rights and obligations. Article 8 of this document explicitly refers to the right to active participation on the governing and management bodies of the university. Later in the document, Article 13 specifies, among other things, students' duty to participate actively and responsibly at the meetings of the bodies they have been elected to. In spite of this, we can state that universities have barely incorporated the debate on participation into their day-to-day functioning (Michavila and Parejo, 2008). Current regulations and laws provide little facility for the incorporation of student participation in the functioning and governing of the university. The constitution of the National Student Council is yet to be completed, and the University student statute still awaits approval; both are provided for in the Organic Act on Universities (LOMLOU ${ }^{2}$ ), but still pending. The section of this Act dedicated to the

\footnotetext{
${ }^{2}$ Act 6/2001 on Universities, modified by Organic Act 4/2007, is the current legislation governing the university system in Spain..
} 
rights of students mentions their right to be represented on governing bodies and within the university (in the terms established under this Act and in the respective university statutes or regulations on its organisation and functioning) and their right to receive academic recognition for their participation in the following university activities and organisations: cultural, sports, student representation, charity/aid and co-operation. However, as student participation on governing bodies is subject to the statutes of each university, their representation is limited in all cases, making representative parity impossible.

Although regulated by law, as mentioned above, research into student participation in Spain has focused on contributing data to demonstrate how little students actually participate on different governing bodies and attempting to analyse the causes for this. Within this body of research, we find the studies conducted by Fouce (2003) and Vaquero (2004), which offer a historical and evolutional perspective of the student movement at Spanish universities. They suggest that a change of model is required if current forms of participation are to be studied. The work done by student representatives is seen as being distant, boring and mostly unnecessary, although diverse and varied student organisations do exist above and beyond student representatives, with differing degrees of involvement. We can also highlight the study carried out by Giménez (2001) on the participation and political positioning of young Catalan university students, which reveals that student participation in elections for the senate ${ }^{3}$ does not reach $17 \%$. These figures coincide with the results of research carried out by the National Youth Council of Catalonia (2001) and that carried out by the Francesc Ferrer i Guàrdia Foundation (1999).

The Urraca Report (Urraca 2005) is deserving of special mention, it being one of the clearest and most up-to-date references to students' interest in highlighting their limited involvement in university governance and their desire to change this situation. More recently, Martín (2007) has presented research conducted at the Autonomous University of Madrid (UAM) aimed at ascertaining norms of participation both inside and outside the University, on the basis of 513 student interviews. The results are concerning: around $70 \%$ of students have never voted in university elections (either for rector or representatives). $40 \%$ claim there is a lack of information. These data are similar to those obtained by González (2007), who states that only one third of university students participate in elections. Results obtained by Basart (2011) and (Soler 2009) are also in line with this. There is, then, a broad consensus on one basic diagnosis: the level of student participation at university is not what one would expect and this may be attributed to inadequate information, a lack of motivation and the need for a new model.

\footnotetext{
${ }^{3}$ The senate (cláustro) is the highest participative governing body of a university, with representatives from the different sectors: professors, students and administrative and service personnel.
} 
Within this context, in May 2005 the University of Cantabria Student Council presented, through its president, a report on student representation participation, in order to offer proposals for its activation (Urraca 2005). The proposals made by the report point to the regulation, simplification and improvement of the process for electing student representatives in the centres and departments of the University, by creating specific regulations, allocating resources, training representatives, etc. The incorporation of these proposals led to a growth in participation from six percent in the 2002 elections of representatives, to $10 \%$ in 2003 and $21 \%$ in 2004 . This confirms that low participation is not due merely to student indifference, demonstrating that participation increases significantly when it is desired, there is awareness of its importance and measures are established to stimulate it. The University of Oviedo Student Council acted in a similar manner in 2005, when it organised the Student Representation Conference "Models and Incentives for Participation". That same year, the Interuniversity Council of Catalonia organised the Conference "Proposals on Student Participation in Universities", with interesting contributions regarding the necessary scale of this participation (Ferrer 2005), possible channels of participation (Pérez 2005) and some proposals for providing incentives for it (Rovira 2005).

All of the above leads us to formulate some initial questions on which to base our proposed research:

- Is it necessary to review the current spaces and regulations related to student participation in the university in order to increase the participation of said group, or are the current structures more than sufficient and often not used to the fullest?

- How should student participation be dealt with at the new EHEA university and what importance should it have for the training of professionals at the university?

- How should this dimension be translated into the functioning of this new university?

In order to respond to these questions, in 2008 a team of professors from the University of Girona conducted a research aimed at analysing the structures and bodies which allow participation in the governance of the University (XXX 2009). The aims were, firstly, to conduct a study broad enough to include information from students and those in charge of university management so as to ascertain the current status of student participation in the functioning of the UdG, and secondly, to conduct an in-depth study which would help to explain the reasons behind the dynamics of participation at the University. Below, we present the objectives and methodology followed in this research, as well as results relating to perceived difficulties in student participation. 


\section{The study}

\section{Study design and instruments}

The study was based on the University of Girona (UdG), a public university of over 12,000 students located in Girona (Catalonia, Spain). We considered that its relatively small size compared to other Spanish universities might favour student participation in the governing structures and highlight different trends to those found in larger universities. In order to study the specific nature of student participation at the University of Girona, then, we set the following objectives: to ascertain the degree of information available to students regarding channels for participation and their perception of the real possibilities and opportunities for participation, to ascertain the degree of student participation in different regulated representative structures of the University, and to analyse whether there are differences (in terms of age, gender, qualifications, etc.) with regard to participation. Using the information obtained, strategies and guidelines were proposed for improving student participation in the faculties and schools of the UdG.

Various different sources (students, study coordinators, vice-deans, databases belonging to the General Secretary's Office of the UdG, etc.), and instruments (student questionnaires and discussion groups with students, semi structured interviews with vice-deans and centre and faculty study coordinators, and the analysis of documents and databases belonging to the General Secretary's Office) were used to achieve the aforementioned objectives. Let us now take a closer look at these.

\section{The questionnaire sent to students and student discussion groups}

An e-questionnaire was designed with 17 questions aimed at ascertaining what information students have regarding channels and structures for participation at the University, and their perception and assessment of the actual possibilities of participating. Of the 9,655 first and second-year students enrolled for the 2007-2008 academic year, we received responses from 673 students, representing $7 \%$ of the total, not a very high number, but similar to results obtained in other studies, such as Giménez (2001), Urraca (2005) and Martin (2007). However, taking into account the fact that this percentage was distributed across all faculties, meaning that for each faculty at least $4.2 \%$ of students responded, and bearing in mind that the sample does represent students from all of the different courses, degree subjects and ages, it has proved useful in ascertaining their perceptions and opinions.

This information was complemented with and qualified by means of discussion groups held with 94 year delegates and student representatives at the eight faculties of the University of Girona. The student response rate was also low here (12\% of participants), which we consider to be a limitation of the study. In some faculties, the discussion group had to be suspended, in others the group was smaller than planned and in still others an individual interview was conducted with the male or female students who were willing to participate. Despite these limitations, the use 
of different sources of information allowed us to use diverse quantitative and qualitative data useful for reflecting on student participation in the university.

\section{Interviews conducted with study coordinators}

The points of view of teaching staff were ascertained via interviews with the coordinators of the different degree courses at the UdG.. We opted to analyse the opinions of these particular professors since, as well as being academic staff at different centres and for different degree courses, it is they who hold most responsibility for the functioning of the different degree subjects, organising boards of studies and attending to students in any matters related to their degree studies. We therefore believe them to have a more global view of the functioning of each degree subject and the student body that forms part of it and participates in its development. A total of thirty-two interviews were conducted, recorded and transcribed.

\section{Documentary research}

The main aim of the documentary research was to ascertain the degree of participation of students in the different regulated participative structures: senates (the highest representative governing body in the university community; their composition is governed by the statutes of each university, with the different sectors of the university community all represented, the majority being professors permanently employed at the university), faculty boards (collegiate governing body of faculties, most of their members are professors permanently employed at the university), faculty governing commissions (collegiate and executive body of the Faculty Board), boards of studies (collegiate body of faculties responsible for studies and discussion of all issues affecting the teaching of each of the degree subjects taught), and electoral consultory boards. The following documentation was analysed to this end: the rules and regulations of the different faculties and study courses (faculty board, governing committee of the faculty and boards of studies), student participation data for the elections held from 2000 to 2008 (rector, senate representatives, and faculty board representatives), and student participation data on university senates from 2000 to 2008.

\section{Results and discussion}

\section{The students' viewpoint}

The results of our study point out that students demonstrate scarce knowledge of spaces and mechanisms for participation; although differences are detected between faculties, most students responding to the questionnaire say they are not well informed $(55.6 \%)$ or not informed at all (24\%) with regard to this issue. In line with this, most students do not know who their representatives are on the different governing bodies of the University. $77 \%$ do not know who their representatives are on the respective boards of studies, $86 \%$ do not know which students represent them on the faculty boards, and over $88 \%$ do not know who their representatives are on the governing committee of their faculty. With regard to senate representatives, only $12 \%$ 
of students say they know who their representatives are. Only in the case of year representatives or delegates is there a majority $(60 \%)$ who know who these are, but when the functions of said representative or delegate include attending the board of studies, this figure falls to $22.3 \%$ of students. Students are completely unaware of the other governing bodies and do not know who their representatives are.

Table 1. Degree of student participation in the different governing bodies where there is student representation

\begin{tabular}{|c|c|c|c|c|c|c|c|c|c|c|}
\hline $\begin{array}{l}\text { Number of } \\
\text { students who... }\end{array}$ & \multicolumn{2}{|c|}{$\begin{array}{l}\text { Board of } \\
\text { studies }\end{array}$} & \multicolumn{2}{|c|}{$\begin{array}{l}\text { Governing } \\
\text { committee }\end{array}$} & \multicolumn{2}{|c|}{$\begin{array}{c}\text { Faculty/school } \\
\text { board }\end{array}$} & \multicolumn{2}{|c|}{ Senate } & \multicolumn{2}{|c|}{ Class assembly } \\
\hline $\begin{array}{l}\text { Have never } \\
\text { participated }\end{array}$ & 593 & $89 \%$ & 620 & $93 \%$ & 640 & $96 \%$ & 640 & $96 \%$ & 436 & $66 \%$ \\
\hline $\begin{array}{l}\text { Have participated } \\
\text { once }\end{array}$ & 49 & $7 \%$ & 27 & $4 \%$ & 16 & $2 \%$ & 13 & $2 \%$ & 55 & $8 \%$ \\
\hline $\begin{array}{l}\text { Participate } \\
\text { occasionally }\end{array}$ & 13 & $2 \%$ & 7 & $1 \%$ & 4 & $1 \%$ & 8 & $1 \%$ & 83 & $13 \%$ \\
\hline Always participate & 11 & $2 \%$ & 11 & $2 \%$ & 6 & $1 \%$ & 5 & $2 \%$ & 82 & $12 \%$ \\
\hline Total & 666 & $100 \%$ & 665 & $100 \%$ & 666 & $100 \%$ & 666 & $100 \%$ & 656 & $100 \%$ \\
\hline
\end{tabular}

The results of our research concur with the aforementioned studies and also with data from the more recent study conducted by Martín (2007) at the Autonomous University of Madrid. The highest percentages (25\%) are for participation in the class assembly, although percentages are low overall. No significant gender or age differences are detected for the different representative bodies. The reasons given by students for non-participation or low participation on governing bodies are mainly ignorance of the spaces and mechanisms for participation (48\% of students) and a lack of time (77.6\%). These data should be analysed with caution, however. It is true that a lack of time is a determining factor for many students in not becoming involved in university life, but it is also true, as González (2007) has already affirmed, that being a student representative is not conditioned by the fact of dedicating oneself solely to one's studies, as it has been found that those students who combine work and studies actually assume more responsibilities. Almost $41 \%$ of those interviewed are of the opinion that it is not worth participating, or that the university climate does not invite participation. In reference to this, one of the students participating in a group discussion stated:

"I get the feeling that it's good for them that we don't really know how it works: so they can do things and then undo them, and if anything happens, since you don't know how it works, you can't participate anyway."

Among the reasons that students give to explain such low figures for student participation is the fact that they perceive the university as an institution which is "not their own" and one which they are only "passing through". In addition to this, we must also take into account the debate regarding the perception students have of their role at university (Johnson and Deem 2003) and the fact that some of them consider themselves mere consumers of a public service. Students also claim a lack of information and communication leads to an ignorance of the University's actual organizational structure, an ignorance of the representative and government bodies 
and their candidates and representatives, and limited understanding of the electoral processes, resulting in the negligible utility they award these. Criticism also exists with regard to the nature of the more institutionalised participative bodies currently in use, which are said to be antiquated, out of touch with young people, unequal with regard to the participation quotas for different positions on said bodies, and ineffective when it comes to decision-making.

\section{The point of view of teaching staff}

Teaching staff, on the other hand, claim that one of the main reasons for low student participation is the fact that a significant majority of students work and study. Heads of studies relate this situation to a special attitude of modern-day students which leads them to not award as much significance to their studies as was the case in previous eras or, at least, as much as teaching staff think they should award them. This situation, according to those in charge of different degree subjects, is true of all faculties.

"I would say that they are not involved; I would say that they have not accepted that education, their degree, is not only the physical space, but the academic space, it's not theirs, they are in it, they occupy it, but it isn't theirs, let's say, to own, and therefore they do not have an awareness of involvement to make them intervene and make demands, requests, modify, intervene in processes of change, because they don't come to see themselves as responsible for it, but rather see themselves as receivers instead, and they even modify the perception of user that in some ways is also being promoted, user-client..." (interview 3).

In some interviews with academic heads, an issue arises that also has to be taken into account when analysing the factors that explain student participation. We are referring specifically to the difficulty students have in understanding university problems such as those dealt with by some of the representative bodies, like the faculty boards and senates. The words of one study coordinator serve to highlight this:

"...many of the debates that take place on faculty boards or on the senate are at times excessively informative, very long, and do not allow for people to make contributions; this discourages participation. Many boards spend two hours informing, informing, informing and informing some more about things that could be written down on a sheet of paper (...). I also think that another element that discourages participation on the senate is that they sometimes talk about very specific aspects which are new to students, the first contact they have with these debates are the papers they receive when the debate is convened and then the subsequent debate on the senate; if participation is required, opinion must be generated beforehand, information provided on how it affects them... And I would say this prior information tends to be what is legally established and legally required and essential, but not enough for students to be aware of how it affects them..." (interview 9). 
Perhaps this explanation may help us to understand why there is low student participation on some governing bodies (senate and faculty boards). We must bear this in mind if we are to generate the changes of approach necessary to facilitate student involvement and participation. However, this argument does not explain why it is difficult to find delegates and representatives on boards of studies, which deal with issues more directly related to teaching and therefore much closer to students' interests and sphere of knowledge.

In the opinion of teaching staff, a first element favouring student participation is for them to be aware of the importance of their presence on certain bodies, such as boards of studies. In some faculties (as is the case with the Faculty of Education and Psychology) students and professors are represented equally on boards of studies. Another element which is without doubt a primary driving force behind student participation is the attitude of teaching staff in helping students to become aware of the important role they have in the University. If students are not aware of their role in the decision-making process at the University, it is very unlikely they will become involved in university bodies, as also pointed out by Lizzio and Wilson (2009). Recent studies carried out at Spanish universities indicate that with the right measures participation increases significantly. Evidence of this is found in the work of the University of Cantabria Student Council (Urraca 2005), which consistently implemented measures on different fronts with the aim of achieving real and effective student participation (reviewing regulations, reviewing electoral calendars and processes, recognising dedication to these representative and participative bodies, and providing specific training in this respect). This also coincides with the conclusions of the more recent study conducted by Cáceres, Lorenzo and Solá (2009) at the University of Granada.

No single vision exists with regard to what student representation represents or should entail. One study coordinator even suggested that if there are no serious problems on an organisational level, then perhaps it is not necessary to interpret low participation as a problem. It is as if participation is only viewed as a possibility established by the regulations and student involvement should not be promoted above and beyond these formal channels. In contrast with this, however, we observe the possibility that, when incentives are provided for participation in said formal channels, students are more likely to participate, not only in formal bodies but also in other spaces where they have a voice, and not only to make complaints but also to ask questions and express concerns. 


\section{Conclusions and proposals for student participation in the university}

Throughout this study we have discovered a fairly widespread perception of the need to make changes to the student model in relation to past eras. It would seem that nowadays most students combine study with work, and consider university to be a training institution that exists alongside many other spaces and resources that often take priority when it comes to participation. Many students do not lead a university lifestyle at university, and participate in other socio-cultural activities in addition to their studies. At the same time, students also attribute low participation in the university to a lack of information and ignorance with regard to how the university functions. In this respect, it is no exaggeration to think that the teaching staff - and the university as a whole - may lack elements and strategies for understanding and connecting with this new type of student. It is not only the students, who are different and more diverse, but also the academic staff (faculties), and the systems that comprise higher education, with the internationalisation of students, new technology development and intensified competition between universities (Johnson and Deem, 2003). It is necessary to think carefully about how the university must adapt to this new emerging profile of both student and society. Furthermore, making a commitment to more student participation in decision-making and functioning processes doubtless requires a change in behaviour and perception from academic staff and management teams. It involves a greater distribution of power and the promotion of participative mechanisms to ensure the representation of all voices, increasing, for example, the quotas of student representation, or decentralising decision-making. This will in turn create a definitive culture that promotes crosscultural alliances and collaboration (Temple and Ylitalo 2009).

Taking the study results into account, and assuming, as we have argued in previous paragraphs, that the study does have its limitations, we present some reflections and proposals for improving university spaces and bodies.

Universities might consider making greater efforts to guarantee the provision of quality information. This means providing clear information with regard to the rules and regulations of all boards and governing bodies involved in the functioning of the university, and providing more and better information on the rights of students, as also highlighted by CC-HER Bureau (2000), Menon (2003) and Kuruzum, and Asilkan and Bato (2005). Professors responsible for managing studies play a fundamental role in promoting student participation in the different degree subjects and, also indirectly, in the rest of university life, as also stated by Menon (2003) and Lizzio and Wilson (2009). In this respect, we would also like to highlight the importance of a positive attitude on different organisational levels towards students' proposals and the establishing of trusting working relationships with student representatives. In order to improve information, consideration should also be given to the provision of spaces and times for student representatives to be able to inform and consult students. 
It is also important to maintain and improve formal spaces for participation, paying special attention to student electoral processes. In order to make them more flexible and reduce their complexity, it is proposed that a regulation be made to unify and simplify all electoral processes, holding them all on just one day, facilitating more information and making them more convenient for students to participate in.

Actions might also be undertaken to facilitate student involvement in the different governing bodies of the university and at different levels of decision-making, thereby promoting more decisive than consultory participation from students. The university might consider giving more of a voice and vote to certain governing organs, particularly those closest to the academic and educational life of students, whilst also making the functioning and decision-making of these bodies more transparent. By way of example, it could recognise student faculty assemblies as formal bodies of debate and decision-making for the student corpus, establish bodies where representation is equal between students and other members of the university, or give students more time on governing bodies to present their needs and proposals (Menon, 2003). Another strategy would be to adapt the pace of information and decision-making of the different governing bodies to the capacity of student representatives, so that they might organise and consult their fellow students, and facilitate their adaptation to the dynamics of these bodies (welcome protocol, documentation, presentation, etc.).

The educational nature of participation on governing bodies of the university and the dedication this requires should be considered an important educational process. In this respect, we propose participation as a student representative on different governing bodies is recognised with the awarding of a certain number of university credits. This proposal, which receives a majority backing among the student body, is being assessed in different European areas. The need for this was established at a Bologna Follow-up Seminar entitled Student Participation in Governance in Higher Education, organised by ESIB and held in Oslo in 2003. However, this measure may prove to be a double-edged sword and not lead to truly motivated active participation that could really improve the university, and its implementation therefore needs to be studied carefully.

A further consideration would also be to offer participation training at the university itself, providing specific training for student representatives. As highlighted by Lizzio and Wilson (2009), certain skills and attitudes are required for fulfilling the duty of representation, which is why it would be convenient if universities were to provide training and mechanisms for acquiring and improving these skills. Means of achieving this could include students receiving credits for participation, promoting peer mentoring networks, or making use of the educational space provided by the classrooms themselves. We should not forget that this daily and constant space is without doubt the place where most can be learnt with regard to participation and, if possible, long before entrance to university (Wilson 2002). 
Finally, student participation can be promoted in other ways than focusing solely on students. The teaching staff are really the ones who promote - or inhibit student participation through their attitudes and the resources they use to facilitate the information and participation processes. It would seem obvious that if professors do not show themselves to be clearly predisposed towards and involved in the university, it is unlikely they will be able to work in this direction with the students. As Zabalza (2009:70) states, "a good part of our ability to influence students stems precisely from what we are as people, from our way of presenting ourselves, from our means of relating to them." It is for this reason that it also seems important to devise strategies to stimulate professor participation and offer training to academic and management staff in getting to know and connecting with the new profile of university student and fostering more inclusive participative processes for the student sector.

In Europe we find ourselves in a period of profound change when it comes to universities, change that affects not only the structure of different degree subjects, but also the content and methodology of university teaching and education itself. It is therefore a good time to consider the role we wish students to have within the university and which spaces, processes and means of education we are going to place within their reach if they are to achieve the competences considered desirable. It is evident that the classroom space and teaching staff are key elements in this, but it is also clear that they are not the only ones. We are convinced that student participation in the governance and functioning of the university, as well as being a right, is also a powerful educational process that can be used in different spaces and at different stages of university life as a primary complement to students' education and professionalization. It is obvious that not all students will want to or be able to achieve the same commitments or levels of participation. We should not, however, allow this to deter us from thinking of different participative structures and processes, from the space closest to the student body, to participation in the university's governing council itself, that facilitate this right to the maximum and allow students to take advantage of the learning and benefits that this entails. One learns through participation, and it therefore makes no sense that upon arrival at university the space for democratic participation is not considered fundamental; neither does it make any sense that students do not yet play a greater and more demanding role, especially when we discover that many of the competences considered transversal for the degree subjects being taught are being put to use in these channels of and structures for participation.

\section{References}

Ahmed, M., Denton, M., O’Connor, J. and Zeytinoglu, I.U. 1999. Gender Patterns in Faculty Participation: A Decade o experience at a Mid-sized University. The Canadian Journal of Higher Education, XXIX, (2-3): 1-32. 
Andolina, M.W., Jenkins, K., Zukin, C. and Keeter, S. 2003. Habits from Home, Lessons from School: Influences on Youth Civic Engagement. PS: Political Science \& Politics 36: 275-280.

Basart, A. 2011. Factors per a l'anàlisi de la participació dels estudiants. El Butlletí. Publicació bimestral d'AQU Catalunya, 52.

Becerra, J. 2006. La escasa participación estudiantil alerta a la comunidad universitaria. El Mundo (sección Campus), 18 de octubre.

Benedicto, J., and Orán, M.L. 1999. Aprendiendo a ser ciudadanos. Experiencias sociales y construcción de la ciudadanía entre los jóvenes. Madrid: Injuve. Ministerio de Trabajo y Asuntos Sociales.

Cáceres, M. P., Lorenzo, M. and Solà, T. 2009. El liderazgo estudiantil en la universidad de Granada desde una visión introspectiva. Bordón. Revista de Pedagogía 61 (1): 109-129.

Cainzos, M. 2006. Participación de los jóvenes españoles en manifestaciones. Comparación con los jóvenes europeos y análisis de sus determinantes. Revista de Estudios de Juventud 75: 121-153.

CC-HER Bureau. 2000. Universities as Sites of Citzenship and Cívic Responsibility, Document DGIV/EDU/HE 36. Strasbourg: Council of Europe

De Boer, H. and File, J. 2009. Higher education governance reforms across Europe. Brussels: European Centre for Strategic management of Universities (ESMU)

Ferrer, M. 2005. La participació estudiantil a les universitats de Catalunya. Les oportunitats i el context de participació, Ponencia presentada en las Jornades sobre la participació estudiantil a les universitats. Barcelona.

Fouce, J. G. 2003. El movimiento estudiantil español a lo largo del tiempo: la transición y los años 90. Un anàlisis cualitativo. Nómadas, 7.

Fundació Francesc Ferrer i Guàrdia 1999. Joves $i$ participació a Catalunya. Barcelona: Secretaria General de Joventut, Generalitat de Catalunya.

Fundación Kaleidos.red 2003. Plan estratégico de participación. Gijón: Ediciones Trea.

Giménez, L. eds. 2001. L'associacionisme $i$ la participació estudiantil a les universitats de Catalunya. Barcelona: CNJC.

González, I. eds. 2007. Participació, política i joves. Una aproximació a les pràctiques polítiques, la participació social i l'afecció política de la joventut catalana. Barcelona: Secretaria General de Joventut de la Generalitat de Catalunya.

Jones, G., Sanan, T. and Goyan, P. 2004. The academia Senate and Univerity Governance in Canada. The Canadian Journal of Higher Education, XXXIV (2): 3568. 
Johnson, R., and Deem, R. 2003. Talking of students: Tensions and contradictions for the manager-academic and the university in contemporary higher education. Higher Education 46: 289-314

Kuruuzum, A., Asilkan, O. and Bato, R. 2005. Student participation in Higher Education Institucions in Turkey. Higher Education in Europa 30 (3): 345-355.

Lizzio, A., and Wilson, K. 2009. Student participation in university governance: the role conceptions and sense of efficacy of student representatives on departmental comités. Studies in Higher Education 34 (1): 69-84

Martín Cortés, I. 2007. La participación política de los estudiantes universitarios dentro y fuera de la Universidad. Panorama Social 6:119-132.

Menon, M.Eliophotou, 2003. Student involment in University governance: a need for negotiated educational aims?. Tertiary Education and Management 9: 233-246

Michavila, F., and Parejo, J.L. 2008. Políticas de participación estudiantil en el Proceso de Bolonia. Revista de Educación, número extraordinario, 85-118.

National Youth Council of Catalonia. 2001. L'associacionisme $i$ la participació estudiantil a les universitats de Catalunya. Barcelona: CNJC.

OECD. 2008. Tertiary Education for the Knowledge Society (Vol. 1 and 2). Paris: OECD

Pérez, D. 2005. Formes de participació: quins canals?. Ponencia en las Jornades sobre la participació estudiantil a les universitats, Barcelona.

Persson, A. 2003. Student participation in the governance of higher education in Europe. Steering Committee on Higher Education and Research, Strasbourg: Council of Europe.

Rovira, M. 2005. Balanç de la participació estudiantil a les universitats. Ponencia en las Jornades sobre la participació estudiantil a les Universitats, Barcelona.

Soler, P. 2005. Les polítiques de joventut durant el període democràtic. Educació $i$ Història, 8: 283-307.

XXX 2009.

Temple, J., and Ylitalo, J. 2009. Propoting Inclusive (and Dialogic) Leadership in Higher Education Institucions. Tertiary Education and Management 15 (3): 277-289

Urraca, J. L. 2005. Informe de participación sobre la representación estudiantil en el Consejo de Gobierno de la Universidad de Cantabria. Cantabria: Universidad de Cantabria.

Vaquero, C. 2004. El movimiento estudiantil universitario. De la Ley de Autonomía Universitaria a la Ley Orgànica de Universidades. Mientras Tanto 91/92: 155-176.

Wilson, S. 2002. Student participation and school culture: a secondary school case study. Australian Journal of Education 46 (1): 79-102. 
Zabalza, M. A. 2009. Ser profesor universitario hoy. La Cuestión Universitaria, 5, 6981.

Zuo, B., and Ratsoy, E.W. 1999. Student Participation in University Governance. The Canadian Journal of Higher Education XXIX (1): 1-26. 